\title{
IMPLEMENTATION OF TAWHID THROUGH MORAL EDUCATION TO BUILD SANTRI'S CHARACTER IN AL ISLAM ISLAMIC BOARDING SCHOOL LAMONGAN
}

\author{
Din Muhammad Zakariya \\ e-mail: dinmzakariya70@gmail.com
}

\begin{abstract}
This study aimed to understand how tawhid education in Al-Islam Islamic boarding school Tenggulun, and how tawhid implement in moral education to build santri character and how far tawhid and moral relevance in character building and its effect to santri. This study was qualitative, the primary data from this study obtain from literature study, utterances, action, and documentation from institution, directure, head master, teacher staff and santri in Islamic boarding school. The implementation of this study indicated that tawhid education through moral education give strong effect on character building of santri. The effects are tawhid become main basis of education in building character of santri to be moslem who knows their God's purpose and apply it in every life aspect and ready to preach and fight for Islam; has storng character of tawhid; has understanding of aqidah ahlu sunnah wal jama'ah; has strong spirit to preach; has obvious aqidah wala' and baro'; has akhlaqul karimah; and apply it to society.
\end{abstract}

Keywords: Implementation, Tawhid, Moral, Character Building, Al-Islam Lamongan

\section{A. Introduction}

Tawhid as principle of life and its gist underlie every moslem activty. Tawhid science is ushuludin, which is about basic science of religion relates to moral and faith matters ${ }^{1}$. Whereas moral is a will of human soul that can cause good deed easily, because

\footnotetext{
${ }^{1}$ Hamzah Ya'qub,Etika Islam: Pembinaan Akhlaqulkarimah (Suatu Pengantar).Bandung: CV Diponegoro. Cet. IV.1988
} 
of habit. Good Morality according to Islam view must be based on faith. Then, faith is not only saved in the heart, but also expressed in the real deed and in the form of alms or good deed. If the good deed done, expressed from faith, it can be called that the faith reach out completness, because it has been realised. Therefore, it is clear that akhlakul karimah (good morality) is a part of faith chain.

Otherwise, bad moral is moral that violates faith principle. Even if the outward deed in is good. However, if the starting point is not because of faith, it will not get judgment on the side of Allah ${ }^{2}$.

Therefore, it is clear that the different value of good deed of believers and unbelievers. The relation between moral and ethics is refllected in the Rasulullah SAW statement as follows: from Abu Hurairah r.a, "Mukmin who has perfect faith has the best character"(HR. Tirmidzi). ${ }^{3}$

The relation between Moral Science and Tawhid Science at least can be seen in these three analysis as follows:

1. It is seen from the object discussed.

Tawhid science discuss about God either from his Dzat, nature, or deed. The steady trust to the God will be base to direct good deed done by human only because of Allah. To direct human become sincere, and his/her sincere is a good moral. Allah SWT. said:

"And they were not commanded except to worship Allah, [being] sincere to Him in religion, inclining to truth, and to establish prayer and to give zakah. And that is the correct religion.” (QS. Al-Bayyinah, 98:5).

2. It can be seen from its function.

Tawhid science will person to not only remember six pillars of faith with the dlil but also the important thing in order to tawhid person imitate the pillars. If we believe Allah has noble characters so it is better to tawhid human immitate that noble characters. The pillars of faith that need to be developed are:

a. Belief in Allah Most High

\footnotetext{
${ }^{2}$ Hamzah Ya'qub,Etika Islam: Pembinaan Akhlaqulkarimah (Suatu Pengantar), pg. 18, Bandung: CV Diponegoro. Cet. IV.1988

${ }^{3}$ Hamzah Ya'qub, op.cit, pg.18
} 
If people believe to Allah and His 99 noble characters so that the Asmaul Husna must be practiced in their life. Therefore, believing to Allah will give effect to build their good character.

b. Belief in the Angles

What means here is to make human immititate angles' good character i.e. to be honest, trust, not ungodly, and obidient to do whatever Allah asked.

c. Belief in Books of Allah (Al-Qur'an)

Morally, it is necessary to make Al-Qur'an as a referee, judge, and priest in our life. Accidentally, we take moral fit to Al-Qur'an.

d. Belief in the prophets

There is noble character in the prophets, partically in the Mohammed prophet. We, as human, are ordered to model those phrophets' character. Thus, belief to the prophets will build noble character. In addition, it can be strengthen by modelling prophets' nature i.e shidiq (truthfulness), amanah (trustworthiness), tabligh (advocacy), and fathanah (wisdom).

e. Belief in resurrection

From the morality side, the effort to aware that all of the deeds in this world must be liable latter in the hereafter. The happines of life in the hereafter will be determined by good deeds and as much as possible encourage people to have work ethic to always do good deed during their life.

f. Belief in predestination and decree

It is to make the one who is belief in God always willing to be grateful on God's decree and to accept all His decree. Those deeds are noble character.

3. Understanding from the Closeness of Relationship between Faith and Good Deed.

Relationship between faith and good deed can be seen in Al-Qur'an and Hadist. Such as (QS. Al-Nisa, 4: 65, Al-Nur, 24: 51, Al-Anfal, 8: 2-4). If we concider those surahs carefully, all of those are about the relation between faith and good deed. Those surahs gives guidance with good deed. Those surahs clearly explain that the faith must be manifested in good deed by the form of willingness in accepting prophets' decision toward disputed case among humans, worthy and obedient to the decisions of Allah and His phrophets, his heart tremble when Al-Qur'an read, rely on God, wholehearted pray, charitable donation because of Allah, avoid useless deed, keep their farji (vulva) dignity, 
and no doubt to fight for Allah. Thus, the relationship between faith in tawheed science and moral building in philosophy can be seen clearly. The tawheed science emerge in giving the base on philosophy and the philosophy emerge in giving the explanation and practice the tawheed science. Tawheed without good moral is meaningless, and moral without tawheed is not solid ${ }^{4}$.

So, this show certainly and clearly that the most important thing that should be noticed by teacher and propagandist persuade to true Islam is tawhid education. That was said by Allah Tabaraka wa Ta'ala which mean,

"So be assured that there is no god but Allah." (QS. Muhammad: 19). Then, it had been practiced by prophet Muhammad SAW and that have been taught by him5.

Pesantren is identical with institution that focus on moral and aqidah also other science and deed like a foundation of building. It also like stem a tree. Just as a building cannot stand without foundation and the tree cannot erect without its stems, so also the deed and science of a person cannot be useful without a straight aqidah. Hence, the attention to aqidah issue should take precedence over the attention to any matter; whether it's food, drink or clothes. For that aqidah will give a mukmin a true life, whereby his/her soul become clean, of which his/her righteous deeds, by which his/her obedience can be acceptable, and therefore his/her degree will be heightened before Allah 'Azza wa Jalla.

Pesantren is an old educational institution inherent in the journey of Indonesian life since hundreds of years ago, it is an educational institution that can be categorized as unique institution and has its own distinctive characteristics, so that currently it shows its brilliant capability through various time with a plurality of polemics faced. Even in journey of its history, pesantren has many santri with Islamic sciences and has a very strong spirit in spreading athentic aqidah, teach and advice people, warn them from all forms of heresy and shirk, and strive hard to deny the heretics.

Pondok Pesantren Al-Islam Tenggulun Solokuro Lamongan is one of the famous enough pesantren because it is often associated with some Bali bombers, so some people consider that the aqidah tawhid taught in the pesantren has deviated from the aqidah ahlus sunnah wal jamaah and more likely to khowarij aqidah sect that gave birth to people of

\footnotetext{
4. Abuddin Nata, Ahlak Tasawuf dan Karakter Mulia, Jakarta: Rajawali Pers, 2013), hlm. 17-19

${ }^{5}$ Salim bin 'Ied al-Hilali, ma'alim al-manhaj as-salafi fi at-taghyir. Kairo: al-maktabah al-salafiyah, 1394 H, cet I. 42
} 
wild and violent character. the tawhid taught whether it has become part of the morals of everyday life of educators and santri in the pesantren or after they finish their study there.

This prompted the author to conduct research on allegations directed to the pondok pesantren Tenggulun Al-Islam. May Allah always guide us in His righteous path and facilitate us in practicing tawhid and implement it in our life by having good moral which will bring glory in the world and the hereafter.

\section{B. Research Method}

This research is qualitative phenomenologic by taking Gzrounded method, which is to find a new theory based on the data found in the field, or develop the theory formulation/develop theoretical conceptualization based on the data. ${ }^{6}$

The primary data expected from this research was based on literature review as well as data on words and actions, the secondary data was documents. The data on words and actions and written data were obtained from the institution, the director, the principal, the theacher, and santri of the boarding schools. It was also needed data that was more related to the object of research from public figures and print of media sources.

The required data collection used interview method, observation and documentation as well as studying related books. the interview method used general guidance interview, so that the interview process was bound by the outline questions based on research problem. ${ }^{7}$

This research belongs to qualitative research category, which meant the data presented in the verbal form, not in the form of numbers. The data in the verbal form often appear in different words with the same intent, or vice versa. ${ }^{8}$

The analysis began by writing the observation or interview. Further, the data obtained were analyzed by using coherence interpretation. The analysis was done by combining the data from the method and then interpretation done to describe the meaning and the relationship between them behind the data information.

\section{Result and Discussion}

\section{Tawhid Description}

\footnotetext{
${ }^{6}$ Muhadjir, Noeng, Metodologi Penelitian Kualitatif, Yogyakarta, Rake Sarasin, 1996 : 90

7 Moleong, Lexy, Metode Penelitian Kualitatif, Remaja Rosdakarya, Bandung, 2000 : 136

8 Muhadjir, Noeng, Metodologi Penelitian Kualitatif, Yogyakarta, Rake Sarasin, 1996 : 24
} 
Tawhid is the glorifying of Allah from all His creatures with full appreciation, and sincerity to worship Him, leave worship other than to Him, and justify His Noble names (asma'ul husna), and His attributes the Most Perfect, and denying the less of Him ${ }^{9}$.

A faithful belief in God, also to what is obligatory for Him in His uluhiyah and rububiyah, faith in His prophets, to the ressurection, to predestination and decree, and to believe in all the authentic texts in the form of religious subjects (usululuddin), all unseen things and its news, and what has been agreed by salafus shalih. It also surrender to Allah ta'ala in the matter of law, command,predestination and shari'at, and submit to the Messengers of Allah with obedience to them, punish and follow his instructions.

\section{Education in Pondok Pesantren Al-Islam}

Khittah of Pondok Pesantren Al-Islam are two main points, as follows:

1) To establish muslim generation to be ready to implement Islam in a kaffah (comprehensively) in all aspects of life.

2) To prepare the cadre of ulemas amilin fi sabilillah.

The targets that will be achieved is to establish a characteristic of Muslim generation such as:

\section{a. Salimul Aqidah}

The generation that has pure tawhid in all life.

b. Shahihul Ibadah

The righteous worship that qualifies, that is sincere intention for Allah and only wishes Allah's pleasure and in its execution follows the example of the prophet and is actually carried out in real deed.

c. Matinul Khuluq

Noble characted is a character exemplified by the prophet Muhammad. The character of him is Al-Qur'an as explained by Aisyah when asked about the prophet Muhammad character, then she replied: "his character is Al-Qur'an".

\section{d. Mutsaqoful Fikri}

\footnotetext{
${ }^{9}$ Shalih Fauzan bin Abdullah al Fauzan, hal. 15
} 
An extensive scientific insight as what Ali bin Abi Talib was advised means: "Teach your kids science and beautify their culture because they will live in a time different from yours".

e. Qowiyul Jismi

A strong, healthy body capable to assume the responsibility of message and to face its challenges.

f. Qodirun alal Kasbi

Able to live independently, not become burden of others and full of optimism as said by imam Syafi'i which means: "I .... If I live will not be lack of food ..... and if I die will not be short of grave ".

\section{g. Nafi'un Li Nafsihi wa Li Ghairihi}

Beneficial to himself, society, people and nature entirely, as Allah said which means "And We have not sent you but as mercy for all the worlds".

h. Mujahidun Li Dinihi

To have soul of mujahid, to exert all of the potential to establish Islam (iqomatuddin) in the earth.

Such generation, after they practice their knowledge, preach, struggle with sincerity, and constantly tafaqquh fiddin in the midst of the ummah so that ulema amilin fi sabilillah InshaAllah will emerge.

\section{Relevance between Tawhid and Character Education}

The purpose of education is to worship Allah Almighty. Thus, the main characteristic of Islamic education and that distinguishes it from education in general, is that Islamic education must be based on tawhid and oriented to the happiness/success of life in the world and the happiness of life in the afterlife.

This is in tune with the concept of education applied in Pondok Pesantren AlIslam which has based on tawhid as has been described in the discussion of tawhid and character education.

From the first level, the santris were taught by the nature of tawhid which is not merely enough to recite and memorize it, but they were taught with the conditions demanded from it, no meaning to anyone unless the conditions are met. Thus, it generated the deed as a part of their character. 


\section{Effect of Tawhid Implementation through Character Education on Santri's Character Building}

By teaching tawhid as a basis in shaping the santri's aqeedah, giving a strong influence on the formation of santri's character. Among the effects arising are as follows:

1) To have strong morality and aqeedah of tawhid

Because every second and movement of life, it is worthy of worship to Lord, not associating Him with anything, and commitment to live the life guidelines of Him. They are Thus, they always live with God, in every second and step always remember Allah, be patient if they get calamity come, be grateful if they get blessing, always expect God's help, return to Him, ask for His forgiveness, accept His destiny in fully submission, expect His pleasure, and take refuge from His wrath.

2) To have understanding about ahlus sunnah wal jama'ah aqeedah

Because the aqeedah guidebooks they learned from the first to the last level, both in or out of class, those are aqeedah ala manhaj ahlus sunnah wal jamaah referring to the understanding of salaf as-shalih.

All of them was an effort so that they really understood the manhaj aqidah ahlu sunnah wal jama'ah in order to be not affected by various kind of aqeedah sect as it is in the hadith:

From Auf bin Malik, he said that: "Rasulullah Shallallahu Alaihi wa Sallam said, “ The Jews will split into 71 groups; 1 group will enter Paradise and 70 will enter Hell. The Cristians split into 72 groups; 1 group will enter Paradise and 71 will enter Hell. By Him in Whose Power is the life of Muhammad, without doubt, my Ummah will be divided into 73 groups. Only 1 will enter Paradise and 72 will enter Hell. When asked about which group will be on the right path, Rasulullah replied: "The main body (Jemaat) of the Muslims". (HR. Ibnu Majah)

At Tirmidzi mentioned that: They are Maa Ana 'alaihi wa Ashaabi (viz they who follow my Manhaj and my companion).

3) To have strong passion to preach 
The program kuliyatul mu'allimin or mu'allimat is a program designed to prepare the cadres of da'i who are ready to be deployed wherever they are assigned to preach and teach the Qur'an and sunnah.

By the provision of Arabic both spoken and written very emphasized since the beginning of learning, it makes them able to refer directly to the master books that have been written by the Imams.

The existence of ushul ad-da'wah subject in the final level, giving them the spirit to preach because it is explained the urgency and various virtues of preach. Among the words of Allah Ta'ala:

"You are the best 'Ummah ever raised for mankind. You bid the Fair and forbid the Unfair, and you believe in Allah."'(QS. Ali Imran: 110)

"There has to be a group of people from among you who call towards the good, and bid the Fair and forbid the Unfair. And it is these who are successful."'(QS. Ali Imron: 104)

Say“ This is my way. I call (people) to Allah with full perception, both I and my followers. Pure is Allah; and I am not among those who associate partners with Allah.”(QS. Yusuf: 108)

"Who can be better in words then the one who calls towards Allah, and acts righteously and says, "I am one of those who submit themselves (to Allah)."(QS. Fushilat: 33)

They are also equipped with fiqh of preaching containing recitation, mainly concerning principles and rules of preaching as a reference for them, as well as correction on the many phenomenon of deviation in preaching.

Fiqh of preaching will be a means to bridge the authentic understanding of Islam, supported by good ability in conveying it to people, so that with this preaching activity ummah will be able to truly witness Islam in self, family, and in the activities of the da'i. Through their preaching. they will carry out the integrity of the people, and expel people from the stupidity to the light of Islam.

4) To have clear aqeedah wala and baro

Because wala and baro are part of the consequences of the aqeedah tawhid which become the basis of the PAI, which stems from an understanding of the sentence la ilaha 
illallah which means there is no god but Allah. With it he denied the deity from other than Allah and set him only for Allah alone.

From the understanding of prophet Muhammad said which means purify complience to the things commanded by him, and leave everything banned and prevented by him.

Shaykh al-Islam Ibn Taymiyyah said, "There is no happiness and perfect pleasure for the heart except in the mahabbatullah (love of Allah) and taqarrub (approach of self) to Him with the things He loves. Mahabbatullah cannot be realized except by turning away from all that is loved besides Him. This is the essence of la ilaha illallah. This is the religion of Ibrahim al-khalil and all prophet. ${ }^{10}$

Thus, the sentence la ilaha illallah is baro dan wala (reject and asign). Wala to Allah, His religion, His books, His prophet's sunnah, and His righteous servants, and baro from every taghut but Allah, just like His say:

"Now, whoever rejects the taghut (the Rebel, the Satan) and believes in Allah has a firm grasp on the strongest ring that never breaks." (QS. Al-Baqarah: 256).

In this case Shaykh Muhammad ibn Abdul Wahab said, "Know that a person has not become a believer in Allah except by denying taghut. The argument is the aforementioned. ${ }^{11}$

Tawhid sentence is a loyality to Shari'ah Allah, as He says:

"(O humankind) follow what has been sent down to you from your Lord, and do not follow any masters other than Him. Little you heed to advice.” (QS. Al-A'raf: 3).

"So, never by your Lord! Never shall they become believers, unless they make you the judge in the disputes that arise between them, then find no discomfort in their hearts against what you have decided, and surrender to it in total submission." (QS. AnNisa': 65).

Also baro with stupidity law, as His word:

"Is it, then, the judgement of (the days of) Ignorance that they seek? Who is better in judgement than Allah, for a people who believe?" (QS. Al-Maidah: 50).

There are several hadiths that explain the nature of wala and baro which are part of tawhid sentence consequence, as follows;

\footnotetext{
${ }^{10}$ Ibnu Taimiyah, majmu' al-fatawa. Kairo: mathba'ah al-hukumiyah. 1381H, 28/32.

${ }^{11}$ Abdurrahman bin Qasim, al-durar al-siniyah, Riyadh: Dar al-ifta'. 1385H, I/95.
} 
Ibn Abi Syaibah narrated with his own sanad that Rasulullah SAW said,

"The most solid of all faiths is love for God and hate for Allah."

Imam Thabrani in al-Kabir narrated from Ibn Abbas that Rasulullah said,

"The most solid of the faiths are the reward for God and the enmity of God; love for God and hate for Allah."

Ibn Jarir and Muhammad bin Nasr al-Maruzi narrated from Ibn Abbas that he said, "Whoever loves for God and hates for God, is loyal to God and hostile to God; in fact, that God's guidance will be accepted. A servant will not be able to feel the joy of faith, however much prayer and fasting, before it is so. The brotherhood of fellow human beings has been transformed into mere worldly interests, but it will not benefit them."12

Explaining the words of Ibn Abbas above, Shaykh Sulaiman bin Abdullah bin Abdul Wahab said, "His statement, 'and loyal to Allah', explains something that must exist in love because of God, that is loyalty because of Allah A hint that in this case love alone is not enough. It must be accompanied by loyalty which is a consequence of love. That is the defense, the glorification, the respect, and always with the loved ones, both physical and conjugal. Its statement 'and hostile because of Allah' explains the necessity of hate for Allah. That is expressing hostile attitude with real, like jihad against enemies of Allah, escape from them, and away from them physically and conjugally. This shows that hatred alone is not enough. He must be accompanied by the consequences, as His word,

"Indeed, there is an excellent example for you in Ibrahim and those with him, when they said to their people, "We disown you and what you worship instead of Allah. We disbelieve in you. Enmity and hatred has arisen between us and you forever, unless you belive in Allah alone." (QS. Al-Mumtahanah: 4). ${ }^{13}$

6). To implement tawhid science in everyday life

a) The santris have a firm belief in Allah Robbul alamin that way, will be the basis so that the acts are done solely because of Allah SWT. Thus the science of Tawhid will direct their to be sincere and their sincerity are one of noble character. Allah SWT says in (QS.Al-Bayyinah, 98: 5) which means: "While they would not ordered but to worship

\footnotetext{
${ }^{12}$ Ibnu Rajab, jami' al-ulum wal hikam. Kairo: Musthafa al-bab al-Halabi. 1382H, hlm. 30. Abu Nu'aim,Hilyatul auliya', Kairo: Maktabah as-salafiyah. 1388H, 1/312.

${ }^{13}$ Syaikh Sulaiman, taisir al-aziz al-hamid syarah kitab tauhid, Riyadh: Idarah al-buhuts al-ilmiyah. Ttt, hlm. 422.
} 
Allah, making their submission exclusive for him with no deviation, that is the way of the straight religion."

b) The santris understand that tawhid science requires that a person in tawhid not only memorize the six pillars of faith with the arguments only, but the most important is that they imitate the subjects contained in those pillars. For example, if one believes in angels, then the intent among others is that humans imitate the attributes of the angels, such as the nature of honest, trustworthiness, never rebellious and obedient to carry out all Allah commanded, believe in angels is also intended so that people feel cared for and supervised by angels, so he dared not violate Allah's prohibitions. In this way believing in angels will lead to noble moral improvement. Allah says in QS. Al-Tahrim, 66: 6) which means: Angles who do not disobey Allah in what He orders them, and do whatever they are ordered to do.

Thus, it can be seen clearly there is a close relationship between faiths discussed in the tawhid science with good deeds discussed in the moral science. The tawhid science appears in giving discussion to the moral science, and the moral science appears to provide elaboration and practice of the tawhid science. Tawhid without a noble character will have no meaning and noble character without tawhid will not be firm. Besides, tawhid gives direction to character, and the character gives content to the direction. Herein, it lays the close relationship between tawhid and character in the formation of santri's character.

\section{Conclusion}

Based on the result describedm it could be concluded that:

1. the purpose of Islamic education must be in line with the purpose of human creation in this earth, i.e to worship Allah Almighty. Thus, the main characteristic of Islamic education and that distinguishes it from education in general, is that Islamic education must be based on tawhid and oriented to the happiness/success of life in the world and the happiness of life in the hereafter.

2. Tawheed became the main basis of education in bulding the character of santri to become a Muslim who knows the purpose of his/her creation and apply it in all sides of life and ready to preach Islam and fight for it. 
3. Tawhid implementation through character education provide strong effect on santri's character building. Among effects emerged are:

a) To have strong tawhid character

b) To have ahlu sunnah wal jama'ah aqeedah understanding

c) To have strong spirit to preach

d) To have clear wala and baro aqeedah

e) To have noble character and to apply it in society

4. To be santri who has characters of religious, independent, honest, and tolerant.

\section{E. Bibliography}

Abdul Aziz bin Nashir Al-Jalil Bahauddien `Aqiel, Dimana kita dan akhlak salaf, solo, Aqwam jembatan ilmu, 2013

Abdullah, Taufiq. Islam dan Masyarakat Pesantren Sejarah Indonesia, Jakarta : LP3ES, 1987

Abdurrahman bin Qasim, Al-durar Al-siniyah, Riyadh: Dar al-ifta'. 1385H

Abu ammar,Mizanul muslim, Solo, Cordova mediatama, 2009

Abu Nu'aim,Hilyatul auliya', Kairo: Maktabah as-salafiyah. $1388 \mathrm{H}$,

Al-Atsqalani, Ibnu Hajar, Fathul Baari Syarh Shahih Bukhari, Beirut : Daarul Kutub Al-Ilmiyah, 1410

Al-Asyqar, Umar. Belajar Tentang Allah, Jatiwaringin: Sahara intisains.2008

Al-Hakami, ma 'arij al-qabul. Riyad: idarat al-buhuts. 1399H.

Al Jazairi, Abu Bakar. Akidah Mukmin, Jakarta : Pustaka Al Kautsar, 2002

Al-qahthani, al wala' wal baro', Mekah: dar at-tauzi', 1397H

Al-Syaibany, Omar Mohammad at-Toumy, falsafah pendidikan Islam. Terj. Hasan Langgulung. Jakarta: Bulan Bintang. 1979 M

Asifuddin, Ahmad Janan, mengungkit pilar-pilar pendidikan Islam, Yogyakarta: Suka press. 2010,

Azizy, Ahmad Qodri A, Islam dan permasalahan social; mencari jalan keluar. Yogyakarta: Pustaka Pelajar. 2000

Daradjat, Zakiyah, Ilmu pendidikan Islam, Jakarta: Bumi Aksara. 1992 
Djamas, Nurhayati, manajemen madrasah mandiri. Jakarta: Puslitbang pendidikan agama dan keagamaan. 2005

Hamzah Ya'qub,Etika Islam: Pembinaan Akhlaqulkarimah (Suatu

Pengantar).Bandung: CV Diponegoro. Cet. IV.1988

Hanafi. Teologi Islam (Ilmu Kalam), Jakarta: Pustaka Al-Husna.1980

Hitami, Munzir, menggagas kembali pendidikan Islam. Yogyakarta:

Infinite

Press. 2004,

Ibnu Katsir, Abul Fida', tafsir Qur'anil adim, Beirut : Maktabah al-isyriyah, 2000

Ibnu Qayyim, at-tibyan fi aqsam al-Qur'an, Kairo: maktabah alqohirah 1398H

Ibnu Qayyim, al-qasaid an nuniyah, Pakistan: idarah turjuman as-sunnah, 1398H

Ibnu Rajab, jami' al-ulum wal hikam. Kairo: Musthafa al-bab al-Halabi. 1382H,

Ibnu Taimiyah, majmu’ al-fatawa. Kairo: mathba'ah al-hukumiyah. 1381H

Kamus besar Bahasa Indonesia,Jakarta, PT Gramedia Pustaka Utama, 2008

Langgulung, Hasan, Asas-asas pendidikan Islam. Jakarta: Pustaka Al-Husna, 1992

Langgulung, Hasan, Beberapa Pemikiran Tentang Pendidikan Islam. Bandung: alMa’arif. 1980

Mahjudin, Akhlaq Tasawuf 1: Mu'jizat Nabi, Karamah Wali, dan Ma'rifah Sufi.Jakarta:

Kalam Mulia,2009

Muhammad bin A.W. Al-'Aqil, Manhaj 'Aqiqah Imam Asy-Syafi'I, Jakarta: Pustaka Imam Asy-Syafi'I, 2009.

Mustafa, asy-syaikh Fuhaim, Manhaj Pendidikan Anak Muslim, Terj. Abdillah Obiddan

Yessi HM Basyaruddin. Jakarta: Mustaqiim. 2004

Moleong, Lexy, Metode Penelitian Kualitatif, Bandung :

Remaja Rosdakarya, 2000

Muhadjir, Noeng, Metodologi Penelitian Kualitatif, Yogyakarta : Rake

Sarasin, 1996

Munawir, Ahmad Warson, Kamus al-Munawir, Surabaya : Progresif, 1984

Nata, Abuddin,.Akhlak Tasawuf. Jakarta: PT Rajagrafindo Persada.2008

Ponpes Al-Islam, Khittah Pendidikan dan Tata Tertib Pondok Pesantren AL-ISLAM, Lamongan , Al-Islam press, 2007

Qardhawi, Yusuf, Pendidikan Islam dan Madrasah Hasan al-Banna, Terj. Bustani A. Gani dan Zainal Abidin Ahmad. Jakarta: Bulan Bintang. 1980 
Salim bin 'Ied al-Hilali, Ma'alim Al-Manhaj As-Salafi Fi At-Taghyir. Kairo: al-maktabah al-salafiyah, $1394 \mathrm{H}$, cet I. 42

Sanaky, Hujair AH, Paradigma Pendidikan Islam; Membangun Masyarakat Indonesia. Yogyakarta: Safiria Insania Press dan MSI. 2003

Sayid Sabiq, Aqaid A-sIlamiya ,Bandung, CV. Diponegoro,1993

Shafiq, Muhammad, Mendidik Generasi Baru Muslim. Terj. Suhadi. Yogyakarta: Pustaka Pelajar. 2000,

Sri Narwati, Pendidikan Karakter: Pengintegrasian 18 Nilai Pembentuk Karakter dalam Mata Pelajaran, Yogyakarta: Familia, 2011

Sutrisno, Pendidikan Islam Berbasis Social. Yogyakarta: ar-ruzz media. 2012,

Syaikh Sulaiman, Taisir Al-Aziz Al-Hamid Syarah Kitab Tauhid, Riyadh: Idarbuhuts alilmiyah. $1396 \mathrm{H}$ 